\title{
Biopure MTAD Induces DNA Damage but Not Cellular Death: An In Vitro Study
}

\author{
Juliana Soares Roter Marins ${ }^{a}$ \\ Luciana Moura Sassone \\ Daniel Araki Ribeirob
}

\section{ABSTRACT}

Objectives: The purpose of this study was to evaluate the capacity of BioPure MTAD to induce genetic damage in vitro. Genotoxicity was assessed by the single cell gel (comet) assay.

Methods: Chinese hamster ovary $(\mathrm{CHO})$ cells or murine fibroblasts cells were exposed to increasing final concentrations ranging from 0.1 a $10 \%$. All treatments were performed for 1 hour at $37^{\circ} \mathrm{C}$. The negative control group was treated with vehicle control (phosphate buffer solution - PBS) for 1 hour at $37^{\circ} \mathrm{C}$ and the positive control group was treated with methylmetanesulfonate (at $1 \mu \mathrm{M}$ ) for 1 hour at $37^{\circ} \mathrm{C}$.

Results: Present results showed that the BioPure MTAD was able to promote DNA breakage in $\mathrm{CHO}$ cells only at the highest concentration tested as well as to induce significant increase in tail moment at all tested concentrations in murine fibroblasts.

Conclusions: In summary, our results indicate that BioPure MTAD is a genotoxic agent as depicted by the single cell gel (comet) assay. (Eur J Dent 2009;3:285-289)

Key words: BioPure MTAD; DNA damage; Single cell gel (comet) assay; Cellular death.

\footnotetext{
a Department of Endodontics, School of Dentistry, Rio de Janeiro State University, UERJ, Rio de Janeiro RJ, Brazil.

b Department of Biosciences, Federal University of Sao Paulo, UNIFESP, Santos, SP, Brazil.

Corresponding author: Daniel A. Ribeiro, DDS, PhD Departamento de Biociências

Universidade Federal de São Paulo - UNIFESP

Av. Ana Costa, 95 Vila Mathias Santos - SP Brazil

Zip code: 11060-001

Phone/Fax: +55 1332222048

E-mail: daribeirolunifesp.br, daribeirolapq.cnpq.br
}

\section{INTRODUCTION}

In order to achieve good prognosis, the endodontic therapy should eradicate bacteria and consequently to produce root canal disinfection before root filling. To date, many methods have been described to reduce root canal microorganisms, including instrumentation techniques, irrigation regimens and intracanal drugs. ${ }^{1}$ BioPure MTAD is one of the recently introduced rinses in the dental market for this purpose. Evidences suggest that it has the ability to remove the smear 
layer and also exert a potent antimicrobial activity. ${ }^{2-4}$ Doxycycline is the primary ingredient contributing to its antimicrobial activity. Citric acid and Tween-80 have an impact on the action of BioPure MTAD as well.

Carcinogenesis is a multi-step process, which is characterized by genetic, epigenetic, and phenotypic changes. ${ }^{5}$ These changes involve genetic damage, mutation in critical genes related to the control of cell division, cell death and metastatic potential, and activation of signalizing or metabolic pathways that give the cells favorable growth and survival characteristics. ${ }^{6}$ With increasing of knowledge of these mechanisms, and the conclusion that most cases of cancer are preventable, efforts have focused on identifying the agents and exposures that cause cancer. ${ }^{7}$ Genotoxicity tests can be defined as in vitro and in vivo tests designed to detect compounds which induce genetic damage including DNA damage, gene mutation, chromosomal breakage, altered DNA repair capacity and cell transformation. In the last decades, genotoxicity assays have gained widespread acceptance as an important and useful indicator of carcinogenicity. ${ }^{8}$ For this reason, genotoxicity data are needed for the comprehensive risk assessment of BioPure MTAD, particularly because there are no previous reports.

As a result, the goal of the present study was to evaluate genotoxic effects of BioPure MTAD in vitro. To evaluate the magnitude of DNA damage, the single cell gel (comet) assay was applied in this setting. This is rapid, simple, and reliable biochemical technique for evaluating DNA damage in mammalian cells. ${ }^{9}$ The basic principle of the single cell gel (comet) assay is the migration of DNA fragments in an agarose matrix under electrophoresis. When viewed under a microscope, cells have the appearance of a comet, with a head (the nuclear region) and a tail containing DNA fragments or strands migrating towards the anode.? Our own recent studies have demonstrated that the single cell gel (comet) assay is a suitable tool to investigate genotoxicity of compounds used in clinical dental practice. ${ }^{10-12}$

\section{MATERIALS AND METHODS}

Cell culture

Chinese hamster ovary cells (lineage $\mathrm{CHO}$ $\mathrm{K}-1)$ were growth to confluence in $75-\mathrm{cm}^{2}$ culture flasks (Corning New York, NY, USA) using Ham 's F-10 medium (Invitrogen Corporation, Grand Island, USA) supplemented with $10 \%$ fetal calf serum and $100 \mathrm{U} / \mathrm{mL}$ penicillin (Life Technologies, USA) and $100 \mu \mathrm{g} / \mathrm{mL}$ streptomycin (Invitrogen Corporation) at $37^{\circ} \mathrm{C}$ with $5 \% \mathrm{CO}_{2}$. Cells were cultured for 5 days prior to treatment with test substances. Confluent cells were detached with $0.15 \%$ trypsin (Invitrogen Corporation) for 5 minutes after that, 2 $\mathrm{mL}$ complete medium was added and cells were centrifuged at $1000 \mathrm{rpm}(180 \mathrm{~g}$ ) for 5 minutes. Cell suspension was counted using a Neubauer chamber and seeded in 96-well microtitre plates (Corning) at a density of $1 \times 10^{4}$ cells per well lat a concentration of $1 \times 10^{6} / \mathrm{mL}$ ).

Murine fibroblast cells (lineage 3T3-L1) were obtained from the American Type Culture Collection (ATCC) and cultured at $37^{\circ} \mathrm{C}$ in a humidified atmosphere of $5 \% \quad \mathrm{CO}_{2} / 95 \%$ air. The cells were maintained in a growth medium containing the following constituents: Dulbecco's modified Eagle'smedium (Invitrogen, USA) with $25 \mathrm{mmol} / \mathrm{L}$ glucose, $1 \mathrm{mmol} / \mathrm{L}$ pyruvate, $4.02 \mathrm{mmol} / \mathrm{L} \mathrm{L}$-alanyl-glutamine, and 10\% fetal calf serum (Sigma, USA). Cells were cultured for 15 days prior to treatment with test substances. Confluent cells were detached with $0.15 \%$ trypsin (Invitrogen Corporation) for 5 minutes after that, $2 \mathrm{~mL}$ complete medium was added and cells were centrifuged at $1000 \mathrm{rpm}(180 \mathrm{~g})$ for 5 minutes. Cell suspension was counted using a Neubauer chamber and seeded in 96-well microtitre plates (Corning) at a density of $1 \times 10^{4}$ cells per well lat a concentration of $1 \times 10^{6} / \mathrm{mL}$ ).

\section{Cell treatment}

The material used was BioPure MTAD (Dentsply, USA) containing a mixture of $3 \%$ doxycycline, $4.25 \%$ citric acid, and $0.5 \%$ Tween-80. This information was mentioned by the manufacturer. To determine the concentration-related effect significance, we were able to test increasing concentrations ranging from 0.1 to $10 \%$. All treatments were performed for 1 hour at $37^{\circ} \mathrm{C}$. These concentrations were established in a previous pilot study conducted in our laboratory. All tested materials were dissolved in phosphate-buffered saline (PBS). The negative control group was treated with vehicle control (PBS) for 1 hour at $37^{\circ} \mathrm{C}$ as well. For positive control group, both cell lineages 
were exposed to methylmetanesulfonate (at $1 \mu \mathrm{M}$ ) for 1 hour at $37^{\circ} \mathrm{C}$. Each treatment was performed three times consecutively to ensure reproducibility.

Single cell gel (comet) assay

The protocol used for single cell gel (comet) assay followed the guidelines purposed by Tice et al. ${ }^{9}$ Slides were prepared in duplicate per treatment. Thus, a volume of $10 \mu \mathrm{l}$ of treated or control cells $\left(\sim 1 \times 10^{4}\right.$ cells) was added to $120 \mu$ of $0.5 \%$ low-melting point agarose at $37^{\circ} \mathrm{C}$, layered onto a pre-coated slide with $1.5 \%$ regular agarose, and covered with a coverslip. After brief agarose solidification in refrigerator, the coverslip was removed and slides immersed to lysis solution (2.5M $\mathrm{NaCl}, 100$ mM EDTA - Merck, St Louis, USA; 10 $\mathrm{mM}$ Tris- $\mathrm{HCl}$ buffer $\mathrm{pH}=10$ - Sigma Aldrich, USA; $1 \%$ sodium sarcosinate - Sigma Aldrich, USA; with 1\% Triton X-100 - Sigma Aldrich, USA; and 10\% DMSO -Merck St. Louis, USA) for about 1 hour. Prior to electrophoresis, the slides were left in alkaline buffer $10.3 \mathrm{mM} \mathrm{NaOH}$, Merck USA; and $1 \mathrm{mM}$ EDTA, Merck, USA; $\mathrm{pH}>13$ ) for 20 minutes and electrophoresed for another 20 minutes, at 25 $\mathrm{V}(0.86 \mathrm{~V} / \mathrm{cm})$ and $300 \mathrm{~mA}$. After electrophoresis, the slides were neutralized in $0.4 \mathrm{M} \mathrm{Tris-HCl} / \mathrm{pH}=$ 7.5) for 15 minutes, fixed in absolute ethanol and stored at room temperature until analysis. All of the steps described above were conducted in the dark to prevent additional DNA damage.

Throughout this study, some diluted and treated aliquots were tested for viability by trypan blue exclusion, ${ }^{13}$ and constantly $>75 \%$ of cells excluded trypan.

\section{Comet capture and analysis}

A total of 50 randomly captured comets per treatment $\left(25\right.$ cells from each slide) ${ }^{14}$ were examined blindly by one expertise observer at 400X magnification using a fluorescence microscope (Olympus) connected through a black and white camera to an image analysis system (Comet Assay II, Perceptive Instruments, Haverhill, UK). For all experiments, we evaluated two image analysis parameters: tail intensity ( $\%$ migrated DNA) and tail moment. Tail moment was calculated by the image analysis system as the product of the tail length (DNA migration) and the fraction of DNA in the comet tail (\% DNA in the tail). In none of the experiments there was a significant difference between these parameters. Therefore, we chose tail moment for the presentation of the results.

\section{Statistical method}

Parameters from the comet assay (tail moment) and cytotoxicity were assessed by one way analysis of variance (ANOVA) followed by post-hoc analysis - Tukey test using SigmaStat software, version 1.0 (Jandel Scientific, Rafael, CA, USA). A $P$ value less than .05 was considered statistically significant.

\section{RESULTS}

The effect of exposure of BioPure MTAD to DNA damage of Chinese hamster ovary cells ( $\mathrm{CHO}$ ) cells is given in Figure 1. The assay was able to detect the significant increase in tail moment of the positive control (hydrogen peroxide-treated cells) compared with the negative control. The Biopure MTAD was able to promote DNA breakage only at the highest concentration (10\%) (Figure 1).

We also evaluated the effect of exposure of BioPure MTAD to DNA damage of murine fibroblasts. The assay was able to detect the significant increase in tail moment at all tested concentrations, observing a concentration-effect relationship (Figure 2).

\section{DISCUSSION}

The aim of this study was to evaluate the genotoxic damage induced by BioPure MTAD using two different cell lines in vitro. The investigation was conducted using the single cell gel (comet) assay.

The alkaline version of the single cell gel lcomet) assay used here is sensitive for a wide variety of DNA lesions. Among them are single- and double strand breaks, oxidative DNA base damage, alkali-labile sites including incomplete repair sites, and DNA-DNA/DNA-protein/DNA-drug cross-linking in any eukaryotic cell. ${ }^{9}$ Tail moment is a virtual measure calculated by the computerized image analysis system considering both the length of DNA migration in the comet tail and the tail intensity. This parameter is one of the best indexes of induced DNA damage among the various parameters calculated by this method.

On the basis of tail moment data, the results of this study pointed out that the alkaline single cell gel (comet) assay in the experimental conditions 
used, detected the presence of DNA damage after a treatment at all concentrations tested for murine fibroblasts. The same picture was observed in $\mathrm{CHO}$ cells only at the highest concentration tested. In fact, our previous data have shown that antibiotics, such as that present in the BioPure $M T A D$, exert genotoxic effect in vivo. ${ }^{15}$ By comparison, some authors have reported that MTAD is a cytotoxic agent as well. ${ }^{16}$ Therefore, it seems that the BioPure MTAD is able to induce cellular injury as a result of DNA breakage for both evaluated cell types. It is important to emphasize that no single test is capable of detecting all genotoxic agents. Although there is general agreement that in vitro assays are useful for identifying potential genotoxic carcinogens and mutagens, the high incidence of positive findings in these in vitro assays with agents that appear not to pose a carcinogenic health risk under certain conditions of exposure implies that reliable cancer health risk determinations cannot be made on the base of in vitro findings alone. ${ }^{17}$ Depending on the responses in the tests, the types of substances tested and on their intended use, one or more in vivo rodent test also have to be conducted. ${ }^{18}$ Such additional testing may include investigation of aneuploidy, chromosome non-disjunction, DNA dysruption and/or primary DNA damage. ${ }^{18}$ Furthermore, the testing should be based on the full knowledge of the chemical its physico-chemical and toxicological properties, mode of action as well as anticipated human exposure cenarios. An understanding of the type of genotoxic insult induced and the nature of the response, with any indications of possible mechanism is crucial. ${ }^{19} \mathrm{All}$ information are gener-

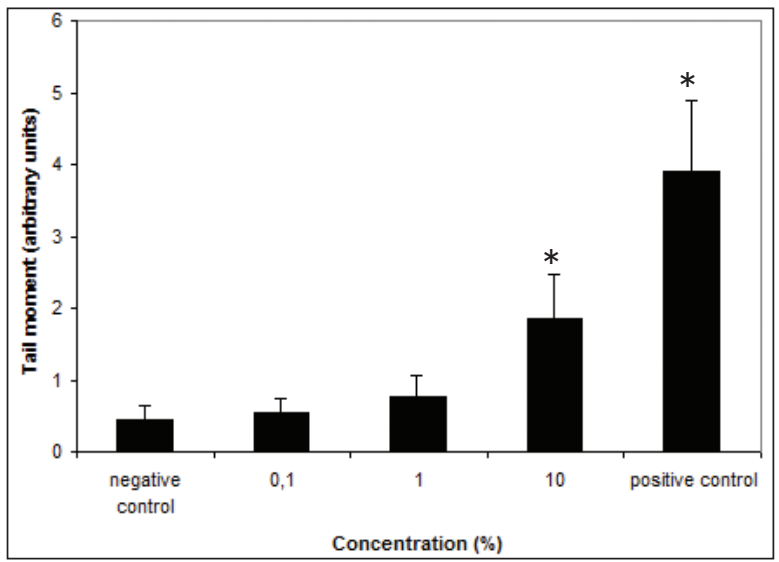

Figure 1. Genotoxic effects following exposure to BioPure MTAD in CHO cells. Results are expressed as mean and standard deviation. ${ }^{*} p<0.05$ when compared to negative control. ally sufficient to conclude the the results observed are consistent with certain mechanisms and responses found.

In the present study, as well as in all of our previous investigations using the single cell gel (comet) assay, we have always excluded comets without clearly identifiable heads during the image analysis. Although it should be emphasized that it is still not completely understood what these hedgehogs actually represent, this type of comet was excluded on the basis of the assumption that these cells represent dead cells, resulting from putative cytotoxic effects of BioPure MTAD rather than primary DNA-damage following a direct interaction between DNA and a genotoxic agent. ${ }^{20}$ In addition, the trypan blue exclusion test was applied in this experimental design to control cytotoxic effects. Although it does not give any detailed information other than membrane stability concerning functional aspects of the cell, it is a standardized and accepted test to concurrently monitor possible other factors influencing DNA migration in the single cell gel (comet) assay, such as cellular death. ${ }^{13}$

\section{CONCLUSIONS}

The present study indicates that BioPure MTAD induces genetic damage in vitro, being the most prominent effect observed in primary murine fibroblasts. Since DNA damage is an important step in events leading from carcinogen exposure to cancer, the results of present study represent a potential alert to the correct evaluation of the potential health risks associated with exposure to these compounds.

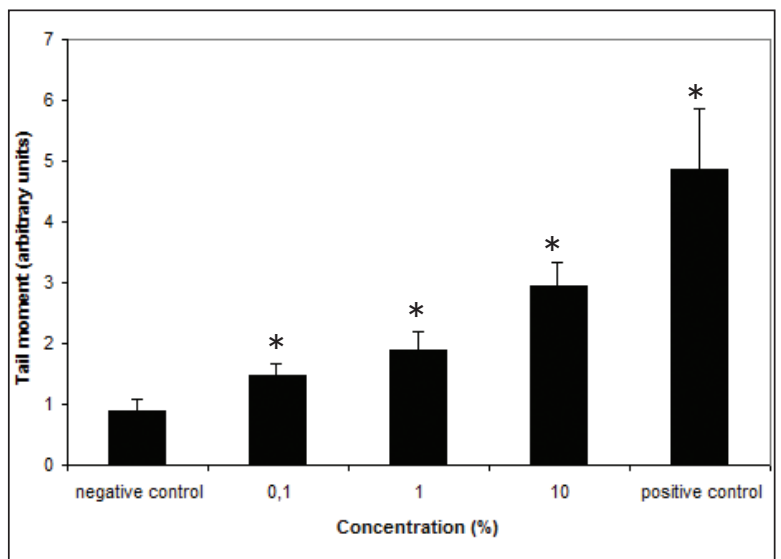

Figure 2. Genotoxic effects following exposure to BioPure MTAD in murine fibroblasts. Results are expressed as mean and standard deviation. ${ }^{*}: \mathrm{P}<.05$ when compared to negative control. 


\section{ACKNOWLEDGEMENTS}

This work was supported by grants from FAPESP (Grant number 07/01228-4). DAR is a recpient of the CNPq fellowship.

\section{REFERENCES}

1. Rosenthal S, Spangberg L, Safavi K. Chlorhexidine substantivity in root canal dentin. Oral Surg Oral Med Oral Pathol Oral Radiol Endod 2004;98:488-492.

2. Mohammadi Z, Shahriari S. Residual antibacterial activity of chlorhexidine and MTAD in human root dentin in vitro. $J$ Oral Sci 2008;50:63-67.

3. Shabahang S, Aslanyan J, Torabinejad M. The substitution of chlorhexidine for doxycycline in MTAD: the antibacterial efficacy against a strain of Enterococcus faecalis. $J$ Endod 2008;34:288-290.

4. Newberry BM, Shabahang S, Johnson N, Aprecio RM, Torabinejad M. The antimicrobial effect of biopure MTAD on eight strains of Enterococcus faecalis: an in vitro investigation. J Endod 2007;33:1352-1354.

5. Sugimura T, Terada M, Yokota J, Hirohashi S, Wakabayashi K. Multiple genetic alterations in human carcinogenesis. Environ Health Perspect 1992;98:5-12.

6. Sarasin A. An overview of the mechanisms of mutagenesis and carcinogenesis. Mutat Res 2003;544:99-106.

7. Ribeiro DA. Do endodontic compounds induce genetic damage? A comprehensive review. Oral Surg Oral Med Oral Pathol Oral Radiol Endod 2008;105:251-256.

8. Auletta A, Ashby J. Workshop on the relationship between short-term information and carcinogenicity; Williamsburg, Virginia, January 20-23, 1987. Environ Mol Mutagen $1988 ; 11: 135-145$.

9. Tice RR, Agurell E, Anderson D, Burlinson B, Hartmann A, Kobayashi H, Miyamae Y, Rojas E, Ryu JC, Sasaki YF. Single cell gel/comet assay: guidelines for in vitro and in vivo genetic toxicology testing. Environ Mol Mutagen 2000;35:206221.

10. Ribeiro DA, Marques ME, Salvadori DM.Biocompatibility of glass-ionomer cements using mouse lymphoma cells in vitro. J Oral Rehabil 2006;33:912-917.

11. Braz MG, Camargo EA, Salvadori DM, Marques ME, Ribeiro DA. Evaluation of genetic damage in human peripheral lymphocytes exposed to mineral trioxide aggregate and Portland cements. J Oral Rehabil 2006;33:234-239.

12. Ribeiro DA, Marques ME, Salvadori DM. Lack of genotoxicity of formocresol, paramonochlorophenol, and calcium hydroxide on mammalian cells by comet assay. $J$ Endod 2004;30:593-536.
13. Mckelvey-Martin VJ, Green MHL, Schmezer P, Pool-Zobel BL, De Méo MP, Collins A. The single cell gel electrophoresis assay (comet assay): a european review. Mutat Res 1993;288:47-63

14. Hartmann A, Agurell E, Beevers C, Brendler-Schwaab S, Burlinson B, Clay P, Collins A, Smith A, Speit G, Thybaud V, Tice RR. Recommendations for conducting the in vivo alkaline comet assay. Mutagenesis 2000;18;45-51.

15. Ribeiro DA, Pereira PC, Machado JM, Silva SB, Pessoa AW, Salvadori DM. Does toxoplasmosis cause DNA damage? An evaluation in isogenic mice under normal diet or dietary restriction. Mutat Res 2004;559:169-76.

16. Zhang W, Torabinejad M, Li Y. Evaluation of cytotoxicity of MTAD using the MTT-tetrazolium method. $J$ Endod 2003;29:654-657.

17. Kirkland D, Aardema L, Henderson L, Muller L. Evaluation of the ability of a battery of three genotoxicity tests to discriminate roden carcinogens and non-carcinogens. I. Sensitivity, specificity and relative precditivity. Mutat Res 2005;584:1-256.

18. Dearfield KL, Moore MM. Use of genetic toxicology information for risk assessment. Environ Mol Mutagen 2005;46:236245.

19. Thybaud T, Aardema M, Clements J, Dearfield K, Galloway S, Hayashi M, Jacobson-Kram D, Kirkland D, MacGregor JT, Marzin D, Ohyama W, Schuler M, Suzuki H, Zeiger E. Strategy for genotoxicity testing: hazard identification and risk assessment in relation to in vitro testing. Mutat Res 2007;627:41-58.

20. Ribeiro DA, Pereira PC, Machado JM, Silva SB, Pessoa AW, Salvadori DM. Does toxoplasmosis cause DNA damage? An evaluation in isogenic mice under normal diet or dietary restriction. Mutat Res 2004;559:169-176. 